\title{
Sciendo PRODUCTION CONTROL IN THE COMPANY
}

doi:10.2478/mape-2018-0060

Date of submission of the article to the Editor: 03/2018

Date of acceptance of the article by the Editor: 06/2018
MAPE 2018, volume 1, issue 1, pp. 475-481

Prof. Henryk Dźwigoł, PhD. Eng.

Silesian University of Technology, Poland

Prof. Lucyna Firlej

Université de Montpellier, France

Andreea Cipriana Muntean, PhD

"1 Decembrie 1918" University of Alba Iulia, Romania

\begin{abstract}
The aim of the article is to get to know the essence of production control in the activity of enterprises. This background presents: the role of control in the enterprise and its classification with particular emphasis on production control. Production control plays an important role in the proper course of the production process. On the one hand, it comes down to the preparation of production plans, creating cost budgets for the company's production parts, and on the other hand to control their implementation. In the scope of production control, economic control of production is taken into account, defined as a direct and indirect impact on the shape of the assortment- and quantity-related structure of production and its course in time and space to ensure, in the given circumstances, the best achievement of the organization's goals. Production control may refer to strategic planning, where the most important is to strike a balance between the flexibility of using production means and workforce, availability of technology and substitute technologies or operational planning, where the key task is to find and eliminate bottlenecks occurring in the production process.
\end{abstract}

Keywords: production controlling, classification of controlling, tasks of production controlling

\section{INTRODUCTION}

Modern management of both production processes and the entire operation of the company needs to make use of any and all management tools available. Control is an important element of the said management tools. Goliszewski (2015) claimed that the subject of control is of a contradictory character: on the one hand it is difficult to identify a company, managed in a modern way, which would be deprived of the said function, on the other hand - in the source literature one can find various concepts and descriptions as to what control is and what it is not. In this context Schäffer and Binder (2008) reasonably stated that control is a relatively young branch of science, highly focused on practical aspects. They also added that control is, at the same time, self-referential and not integrated, to a certain extent, with the international community.

The control system constitutes a complex function which cannot be equated with inspection, since the latter is one of constituents of the control system. The control system should not replace the management system. On the contrary, it supports the company executives in various ways and thus facilitates the management process (Goliszewski, 2015). In this context, the essential task of control is to support company executives in gathering exhaustive information which would allow to take decisions favouring development of companies (Chomuszko, 2015). The control system encompasses all functions of the company, with particular emphasis on financial functions. The system concentrating, to a limited extent, on the environment, allows to elaborate a set of tools to set targets, plan and 
manage the company's earning power (Dźwigoł, 2011). That is why all functions should be adequately integrated and co-ordinated, otherwise the system will not be able to properly operate and support the decision-making process, with a consideration given to signs coming from the inside of the company, as well as its surrounding environment. A comprehensive use of controlling in the company reorganisation process should also take into account 'human capital' present in the company, who, as long as being active and wellinformed, is able to ensure that all above-described functions of control may be fulfilled. Proper motivational system allows for the employees to remain involved in the performance of common goals. Thus, the staff participate in setting and accomplishing tasks of companies (Dźwigoł, 2015a; Dźwigoł, 2015b).

Considering a very dynamic character of modern economic processes and a growing demand of top executives for a wide scope of executive information necessary to take key decisions, it is therefore difficult to imagine the execution of controlling tasks without support of an effective IT system. Such a system should guarantee that the information is used in the best way; however, one should bear in mind that requirements for control-related IT system are particularly complex, and depend, to the large extent, on a type and specific character of the economic entity, and also on the sector in which the said entity operates (Bieńkowska et al., 2017).

According to Plich et al. (2011) the most essential aim of running an economic activity is to achieve results. Due to fierce competition, companies focus on survival strategies available in the market. The companies' executives are forced to take decisions in very short time. They might be supported by control tools, while the said tools were designed to evaluate how effectively particular methods of production planning and managing are employed. It needs to be underlined that the production process has posed a challenge for control-related actions, especially when taking into consideration diversity of factors affecting its effectiveness, e.g. existence of "bottlenecks" which determine the effectiveness of the entire production process or planning rational material outflows in the production process, aimed at reducing reserves and works in progress (Koliński, 2011).

One needs to bear in mind that production control has not been exhaustively covered in professional and scientific literature. The lack of thorough knowledge results in the situations where production companies may avoid control-related actions.

With reference to the foregoing, the article pondered on production control and its essence. In the first part the author discussed the role of control in a company, and presented the classification of control, with a particular emphasis on production control. He lately focussed on tasks of control, taking into consideration both strategic and operational levels.

\section{ROLE OF CONTROL IN THE COMPANY}

Implementation of control in the company requires adopting a certain mindset, the latter evolving around fulfilment of companies' goals. The foregoing was emphasised by Horvath (2006), as he indicated that control should be concentrated on managing the entire subsystem against indicated goals. In compliance with the definition above, the most essential function of control is the co-ordinational function, which, as it was mentioned by Friedl (2003), cannot go without proper focus on achieving determined goals. Chang et al. (2014) added that, having the effective co-ordination and cohesion of companies' actions in mind, one should, in the first place, solve communication-related problems, as the effectiveness of co-ordination and integration are dependent on achieving, transmitting and processing of information. Furthermore, control must be maintained in everyday actions while taking decisions at various levels of management. The company managers, when setting the said goals, shall explain to their staff what the company expects from them (Sierpińska and Niedbała, 2003). That is why, apart from the necessity to determine trends of actions and tasks for responsibility centres, the control is connected to making use of people's motivation, in order to facilitate the process of achieving aims. It triggers a necessity to 
create a motivational system, designed to encourage employees to become fully committed to the fulfilment of organisations' goals (Stoffel, 2013).

Control makes it more likely for companies to survive and develop. The control program should be implemented not only in companies with poor financial results (in order to improve them), but also in companies in good financial conditions, in order to ensure chances of surviving in the market for a longer time (Janiczewski, 2013).

\subsection{Classification of control systems}

Among various classifications of control, as specified in the source literature, one needs to emphasise two classifications: one which takes into account a functional (branch-related) classification, and the other one which takes into consideration the level of management. Both classifications were shown in the Fig. 1.

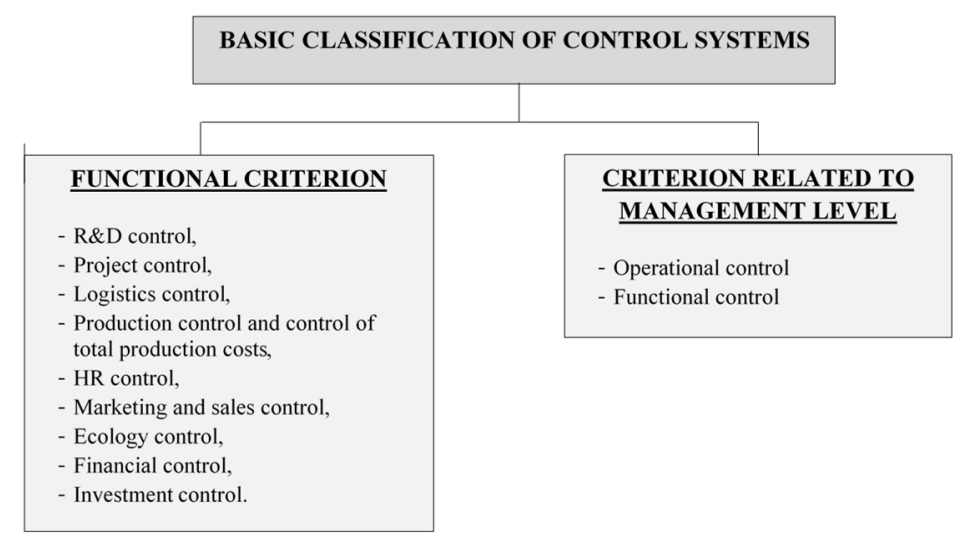

Source: on the basis (Chomuszko, 2015).

Fig. 1. Basic classification of control systems

There is a brief characteristics of selected types of functional control below:

Control of R\&D activity. According to Sierpińska and Niedbała (2003) 'the task of the control system in this area is to manage effectiveness and performance of the said department. Most often than not the said effectiveness does not involve reducing costs at any price, it is reflected by shaping its optimum level, maximising effects with the given expenses'. A thorough analysis which 'might be presented as profits and costs (Sierpińska and Niedbała, 2003) is of essential importance as to taking a decision whether research on a given product would be pursued or not. Developing the control system in such a type of activity mainly involves preparing a balance of costs incurred due to the company's development. An essential aspect of the control system is to plan further actions and budget costs (Chomuszko, 2015).

Logistics control. According to Pfohl (1998) the logistics control should be regarded as a sub-system of control, as a 'fulfilment of control-related tasks in the area of company logistics'. The logistics control should mainly cover the planning of material flow, planning and controlling of logistics costs, stock optimisation and transport planning (Chomuszko, 2015).

Marketing and sales control focuses mainly on rationalising expenses that are necessary to meet sales targets, and on their impact on turnover volume and company profits. It encompasses strategic analyses, planning and controlling of prices and revenues, managing the salespeople (necessity to achieve contribution margins, as set forth in the budget), planning and controlling of promotional activities, analysing the demand for products, taking into accounts customers and sales areas (Chomuszko, 2015).

Production control, as a core of the present study will be described in details in the following subsection. 
One the other hand, taking into account the management criterion, the strategic control is focused on assisting the company managers in fulfilling their long-term goals. It provides organisational conditions to elaborate plans, and adjust them to operational management (Chomuszko, 2015).

Operational control is focused on regulating internal processes in order to manage profits of the company in short-term scale. Furthermore, it is mainly focused on achieving current goals (Wierzbicki, 1994). Within its frames, there occur phenomena of concretisation and verification of concepts elaborated at the strategic scale. Basic tasks of operational control cover co-ordination and joint participation in the process of strategy implementation.

\subsection{Control system in production companies}

Essence of production control

According to Nesterak and Bobáková (2004), in Polish businesses the production control has been playing an essential role in the correct course of the production process.

Its functions cover, - on one hand - preparing short- and mid-term production plans, creating cost budgets for particular production parts of the company (departments, subsidiaries, production sections, production centres), and - on the other hand - supervising how the plans are executed (Nesterak, and Bobáková, 2004).

The main objective of production control is to monitor the activity of the company, and notify managers in production centres of a necessity to adopt specific actions.

Eschenbach (1996) defined production control as a way of supporting the processes of planning, executing and supervising production settings through information and system development. Ossadnik (1996), on the other hand, claimed that production control is a system whose task is to coordinate actions of production managers, aimed at fulfilling the aims of the company. According to Chomuszko (2015) production control, while supporting production management, is to ensure that companies' targets are to be met. On the other hand, Hoitsch (1996) defines the production control (Proco-System) as a process of coordination of production, which supports the management. Coordination system is based on planning, management and control. It provides the management with necessary information, protecting the coordination system in the process of production management. The Figure 2 below shows the concept of production control by Hoitsch.

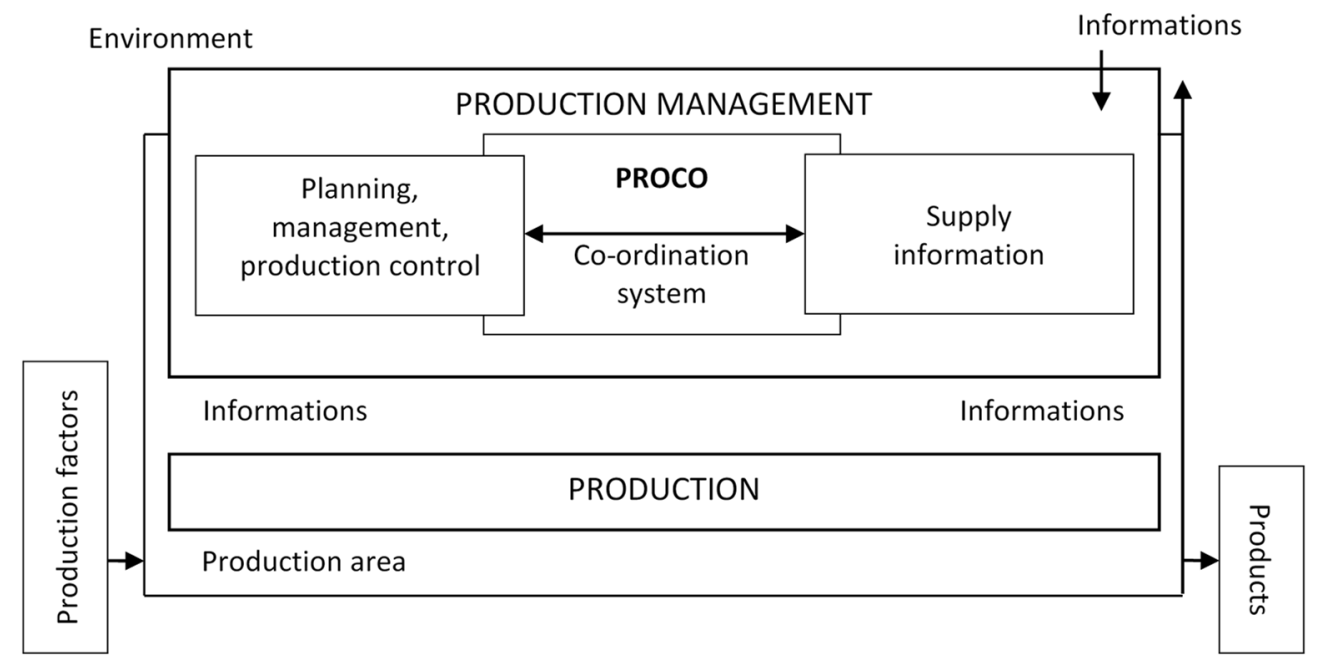

Fig. 2. Concept of production control by H.J. Hoitsch 
Nowosielski (2002) claimed that production control was associated with economic steering of a production process. It influences, in a direct and indirect way, the production structure, as far as its range of products and quality are concerned. It also influences its time- and spacerelated course. A successful implementation of the control system ensures that economic tasks of the entire company will be executed in the most favourable way, given current circumstances.

According to Plich et al. (2011) production control concentrates on:

- production planning and monitoring (input-output in the production process) in order to develop production (also through reducing the production time),

- optimising production programmes, with a consideration given to costs (managing fixed production costs), the duration of the production processes and duration of storing (volume of production, number of refitting),

- determining equity participation (making use of one's own fixed assets) and its reduction.

\section{Tasks of production control}

In the production sector, decisions are taken in order to ensure technological costeffectiveness during manufacturing of goods and services. Decisions taken in this area influence a level of sales turnover, a reduction of sales volume due to production quality, direct costs of payroll for production workers, unit operation costs of machines and devices, direct material costs, a part of general production costs, stock level of finished goods and work in progress or the stock of fixed assets. Decision-takers in production processes are supported by numerous tools, such as: production plans, production resources plans or plans for production and managing (Nesterak and Bobáková, 2004).

Bearing in mind that the area of interest of the production control is very wide, Nesterak and Bobáková (2004) claimed that the production control can be reduced to two main groups: 1 . tasks connected to developing a system of production-related planning and controlling, and 2. indicating what tools might possibly be used in the production management process. According to Niedbała (2004) the tasks of production-related control are a derivative of the basic aim of control, that is 'striving to optimise results, while aiming, at the same time, to maintain payment capacities'. Table 1 shows tasks of production control.

Table 1

Tasks of production control

\begin{tabular}{|c|c|c|}
\hline & \multicolumn{2}{|c|}{ Supporting management with co-ordinated production activity } \\
\hline & as to planning, managing and controlling & as to information safety \\
\hline $\begin{array}{l}\text { System } \\
\text { structure }\end{array}$ & $\begin{array}{l}\text { Creating and adjusting a system of planning, } \\
\text { managing and controlling as to: } \\
\text { - management system structure, } \\
\text { - management system functions } \\
\text { (programming and planning of factors and } \\
\text { processes), } \\
\text { - organising centres and workers, } \\
\text { - management methods, techniques and } \\
\text { tools). }\end{array}$ & $\begin{array}{l}\text { Creating and adjusting a system of operational } \\
\text { activity as to: } \\
\text { - acquiring and analysing information (forecasting } \\
\text { methods and techniques, cost and investment } \\
\text { accounts, measuring and classifying information), } \\
\text { - transferring data (reporting system). }\end{array}$ \\
\hline $\begin{array}{l}\text { System } \\
\text { usage }\end{array}$ & $\begin{array}{l}\text { - support in creating partial plans, } \\
\text { - coordinating partial plans (integrated } \\
\text { planning), } \\
\text { - analysis of deviations within the scope of } \\
\text { control functions. }\end{array}$ & $\begin{array}{l}\text { - gathering, processing and sending information, } \\
\text { - assisting company executives in preparing } \\
\text { summaries (reports), } \\
\text { - preparing customised summaries on request. }\end{array}$ \\
\hline
\end{tabular}

Source: (Steinle and Bruch, 1998).

It transpires, from the Table 1, that the main task of production control is to support coordination and decision-related functions in the company. The said control is designed to support the production, while the latter is a decision-making process. It sets tasks for production cells in the company and ensures that undertaken actions and decisions bring 
about the fulfilment of tasks to the greatest extent. Production control should contribute to the enhancement of managing functions (planning, organising, motivating and controlling) as well as other functions of the company: logistics, administration, sales and finances (Adamczyk, 2015; Czakon, 2008).

The production activity, being the most basic area of the company activity, should be carefully monitored and managed, while the control should support company managers. An essential aspect of the control system is focusing on managing, in a reasonable way, production costs, while maintaining a satisfactory quality of products (Chomuszko, 2015).

The production control may refer to planning at both strategic and operational levels.

As far as strategic planning is concerned, it involves choosing a proper technology which, on one hand, will allow to maintain the quality of goods being produced at a relevant level, while, on the other hand, it will minimise the reliability of the production process. At this planning stage, one should select a specific type of production process which is directly connected to the strategic production plan and possible empowering of a given individual with necessary production resources. The main aim is to achieve a mutual balance between three elements: flexible use of production means and labour force, available technology and availability of replacement technologies.

Production control also refers to planning at the operational level; the operational planning is its centre of attention (Plich et al., 2011). Its main task at this stage is to determine the volume of particular production orders and series, plan to what extent the machines are to be used, and determine the time needed to process every order. The actions influence, in a direct way, the level of planned costs adjusted to production capacities, costs of downtimes and refitting, costs of material shortages, and inventorying costs of finished goods and work in progress. Instead of objectives in the form of costs, there are often tasks in the form of reduced downtimes, minimised lengths of production cycles, minimised deviations of production deadlines or maximised workload of stations (Nesterak and Bobáková, 2004). Furthermore, another important task of control, at this very level, is to eliminate bottlenecks in the production process. The said factor is of importance as it influences processes of production planning and steering. Thus, the production schedule should be adjusted to production capacities and availability of the bottleneck (Trojanowska and Pająk, 2010).

\section{CONCLUSION}

Contemporary companies should make use of all available management tools in order to handle production processes and manage their entire operation. In the times of modern production management, one essential management tool - i.e. control - cannot be ignored. Taking into account the classification of control, the production control is gaining importance for the sake of production management.

The production control has played an essential role in the course of production process. It involves, on the one hand, preparing production plans, creating cost budgets for production areas of the company, whereas, on the other hand, it comes down to supervising its fulfilment. Production control may refer to strategic planning, where the most important thing is to strike a balance between the flexibility of using production means and workforce, and availability of technology and substitute technologies or operational planning, where the key task is to find and eliminate bottlenecks occurring in the production process.

The production control involves economic control of production, defined as a direct and indirect impact on the production structure, as far as its range of products and quality are concerned. It also influences the time - and space-related course in order to provide for the best fulfilment of organisations' goals in given circumstances (Izdebski et al., 2013).

The task of the controller is to make sure that production process is effective and stable. Its actions are focused on guarantees that the manufactured products should be of the highest quality. Thanks to these actions, the company may avoid numerous deficiencies. 


\section{REFERENCES}

Adamczyk, M. (2015). System controllingu w spółce ABC. Zeszyty Naukowe PWSZ w Płocku, Nauki Ekonomiczne, t. XXII.

Biadacz, R. (2000). Controlling produkcji, In: Rachunkowość w nowoczesnej gospodarce, Materiały konferencyjne. Świnoujście.

Bieńkowska, A., Kral, Z., and Zabłocka-Kluczka, A. (2017). IT tools used in the strategic controlling process - Polish national study results. In: $16^{\text {th }}$ International Conference Perspectives of Business and Entrepreneurship Development in Digital Age. September 20-22, Brno, Czech Republic.

Chang, H., Ittner, C.D., and Paz, M.T. (2014). The multiple roles of the finance organization: Determinants, effectiveness, and the moderating influence of information systems integration. Journal of Management Accounting Research, 26(2).

Chomuszko, M. (2015). Controlling procesów. Jak wdrożyć. Warszawa: PWN.

Czakon, W. (2008). Controlling produkcji - wymiary i zasady projektowania, Controlling i rachunkowość zarządcza, 3.

Dźwigoł, H. (2011). Controlling w procesie zarządzania współczesnym przedsiębiorstwem. Gliwice: Wydawnictwo Politechniki Śląskiej.

Dźwigoł, H. (2015a). Bussiness Management. Oxford, U.K: Alpha Science International Ltd.

Dźwigoł, H. (2015b). Bussiness Management. (New Delhi, Chennai, Mumbai, Kolkata). For Sale in India, Pakistan, Bangladesh, Nepal, Bhutan and Sri Lanka only. Indie: Narosa Publishing House.

Eschenbach, R. (1996). Controlling. Stuttgart: Schaffer-Poeschel Verlag.

Friedl, B. (2003). Controlling.Stuttgart: UTB Verlag.

Goliszewski, J. (2015). Controlling. Koncepcja, zastosowania, wdrożenie. Warszawa: Oficyna a Wolters Kluwer business.

Hoitsch, H.J. (1996). Produktionscontrolling, In: Schulte Ch. ed., Lexikon des Controlling. R. Oldenbourg Verlag GmbH: München.

Horvath, P. (2006). Controlling. 10. Auflage. München: , Verlag Franz Vahlen.

Izdebski, W., Skrzyszewska, K., Skudlarski, J., Zając, S., and Aleksandrovna Zayka, S. (2013). The role of controlling in production management. Вісник Харківського національного технічного університету сільського господарства: Економічні науки. Вип. 138.

Janiczewski, J. (2013). Controlling w przedsiębiorstwie transportowym. Zeszyty Naukowe Wyższej Szkoły Humanitas. Zarządzanie, T. 14, Nr 2. Sosnowiec: Oficyna Wydawnicza Humanitas.

Koliński, A. (2011). Przegląd metod i technik oceny efektywności procesu produkcyjnego. Logistyka, 5.

Nesterak, J., and Bobáková V. (2004). Proces budżetowania w controllingu produkcyjnym, In: Urbańczyk E. (red.). Strategie wzrostu wartości przedsiębiorstwa - teoria i praktyka gospodarcza. Zeszyty Naukowe, nr 378, Prace Instytutu Ekonomiki i Organizacji przedsiębiorstw Uniwersytetu Szczecińskiego, nr 43, T. 1. Wydawnictwo Kreos: Szczecin.

Niedbała, B. (2004). Controlling projektów, In: Sierpińska M. ed., Controlling funkcyjny w przedsiębiorstwie. Kraków.

Nowosielski, S. (2002). Controlling w obszarze produkcji. Prace Naukowe Akademii Ekonomicznej we Wrocławiu, nr 956. Wrocław: Akademia Ekonomiczna.

Ossadnik, W. (1996). Controlling. München: R. Oldenbourg Verlag GmbH.

Pfohl, H.Ch. (1998). Zarządzanie logistyką - funkcje i instrumenty. Zastosowanie koncepcji logistyki w przedsiębiorstwie i w stosunkach między przedsiębiorstwami. Poznań: Biblioteka Logistyka.

Plich, M., Rypińska, P., Trojanowska, J., and Koliński, A. (2011). Wykorzystanie wybranych metod planowania i sterowania produkcją w controllingu produkcji. Logistyka, 5.

Schäffer, U., and Binder, Ch. (2008). Controlling as an academic discipline: the development of management accounting and management control research in German-speaking countries between 1970 and 2003. Accounting History, 13(1).

Sierpińska, M., and Niedbała, B. (2003). Controlling operacyjny w przedsiębiorstwie. Centra odpowiedzialności w teorii i praktyce. Warszawa: PWN.

Steinle, C., and Bruch, H. (1998). Controlling. Kompendium für Controller innen und ihre Ausbildung. Stuttgart: Schäffe - Poeschel Verlag.

Stoffel, K. (2013). Controllership im internationalen Vergleich. Unternehmensführung \& Controlling. Wiesbaden: Springer-Verlag.

Trojanowska, J., and Pająk, E. (2010). Using the Theory of Constraints to production processes improvement, In: Kyttner R. ed., Proceedings of the 7th International Conference of DAAAM Baltic Industrial engineering. 22-24th April 2010, Tallinn.

Wierzbicki, K. (1994). Zakres działania i formy organizacyjne controllingu. Ekonomika i Organizacja Przedsiębiorstw, 5. 